\title{
ROLE OF PROBIOTICS IN IMPROVING MICROBIAL LOAD OF BROILER CHICKEN CARCASSES
}

\author{
EL-DOSOKY, H.F.A.; SANYA, T. EL-GHAMRY and AZZA, E.A. HASSAN \\ Animal Health Research Institute, Mansoura branch \\ Email: nogoom.1980@.gmail.com
}

\section{ABSTRACT}

Received at: 9/12/2013

Accepted: 4/2/2014
A total number of 90 one day old chicks were purchased from a poultry company at Mansoura city and divided into three groups (each of 30). All groups were prophylactically vaccinated according to the local routine vaccination programme. The first group (control group) was fed a basal diet (without probiotics), whereas $2^{\text {nd }} \& 3^{\text {rd }}$ groups were fed on the same basal diet supplemented with probiotics. At $42^{\text {nd }}$ days of age, broilers were slaughtered, processed and bacteriologically examined for aerobic plate count $(A P C)$, enumeration of Coliforms (MPN), E. coli count, detection of Salmonellae, Campylobacter jejuni and E. coli where the log mean of $A P C$ in group 1, group2 and group3 were $5.5 \pm 0.9,4.9 \pm 1$ and $4.8 \pm 0.8$ $\log _{10} \mathrm{cfu} / \mathrm{gm}$, the MPN of Coliforms were $3.4 \pm 0.9,3 \pm 0.9$ and $2.7 \pm 0.8 \log _{10} \mathrm{cfu} / \mathrm{gm}$, E. coli count were $3.3 \pm 1,3 \pm 0.8$ and $2.9 \pm 0.7 \log _{10} \mathrm{cfu} / \mathrm{gm}$ with reduction percent from $40 \%$ to $30 \%$ and $33.3 \%$, meanwhile The incidence of Salmonellae were reduced from $30 \%$ to $16.6 \%$ and $10 \%$ and Campylobacter jejuni incidence were reduced from $20 \%$ to $6.6 \%$ and $3.3 \%$ respectively. The experiment was triplicated and the results in group 2 and group 3 were reduced significantly $(\mathrm{P}<0.05)$.

Key words: Probiotics, Microbial load, Broiler chicken

\section{INTRODUCTION}

Probiotics are defined as viable microorganisms (bacteria or yeast) that exhibit a beneficial effect on the health of their host when they were ingested (Salminen et al., 1998). The use of probiotics have started after the study reported by (Nurmi and Rantala, 1973) where the original objective was to control Salmonella infection and occupied the adhesion sites on intestinal epithelium, hence addition of probiotics have the objective of preventing the intestinal colonization of enteropathogenic bacteria in birds since probiotics and pathogenic bacteria compete for nutrients (Silva, 2000). Using of probiotics have been extensively studied world wide as a possible alternative for antibiotics by Jernigan and Kornegay (1985); Stavric and Kornegay (1995); Newman and Jacques (1995); England et al. (1996) and Pelicano et al. (2002). Jin et al. (1996) found that inclusion of probiotics (Lactobacilli and Bacillus subtilis) in the diet stimulated the favorable microbial balance in the gut leading to improving food efficiency and growth performance in broilers, therefore there is a world trend to reduce the usage of antibiotics in animal feed due to residues problems in the final product, most of broiler industry practitioners have been given a growth promoter as an additive in the ration Menten (2001 and 2002).
Therefore, the aim of this work was to evaluate the effect of probiotics as feed supplement on the bacteriological status of broiler chicken carcasses.

\section{MATERIALS and METHODS}

A total number of 90 one-day-old Cobb chicks were purchased from a poultry company at Mansoura city and divided into three groups. All groups were prophylactically vaccinated according to the local routine vaccination programme. Chicks were reared in three separated pens $(3 \times 2 \mathrm{~m})$ under good hygienic conditions.

The first group (control group) was fed on a basal diet (without growth promoters) which mixed first, placed in a clean unused sacks.

The second group was fed on the same basal diet supplemented with Bacillus subtilis spores $4 \times 10^{5} \mathrm{CFU} / \mathrm{gm}$ at $1.5 \mathrm{kgm} /$ ton (Megalo, Amoun Man. Add. EL-obour city, Cairo, Egypt) added to the diet all over the period according to the manufacturer's instructions and thoroughly mixed, placed in a clean unused sacks.

The third group was fed on the same basal diet contained similar proportion of six strains of variable 
organisms namely Lactobacillus acidophilus and Lactobacillus casei, Bifidobacterium bifidum, Aspergillus oryzae, Streptococcus faecium and Torulopsis sps added to the diet at $100 \mathrm{mg} / \mathrm{kg}$ diet all over the period of the experiment and thoroughly mixed, placed in a clean unused sacks and stored at room temperature.

The chicken fed on the aforementioned diets from $1^{\text {st }}$ to $42^{\text {nd }}$ day of age. The chicken was allowed to have free access to a starter diet with crude protein $(21.5 \%)$ during the first three weeks and then to a finisher diet with crude protein $(19.5 \%)$ during the second three weeks and free access of water. The experiment was repeated three times. There was a complete separation between different groups, the house was locked at all times to prevent unauthorized entry. Prior to initiating this study the house was thoroughly cleaned, sanitized, disinfected and new wood shavings litter were placed. At $42^{\text {nd }}$ of age, broilers were slaughtered and processed then placed on ice till bacterial examination. All equipments were cleaned, sanitized using commercial sanitizer after each time.

\section{Bacteriological Examination:}

muscle and skin tissues (25gm) from each chicken were homogenized with $225 \mathrm{ml}$ of $0.1 \%$ peptone water in a stomacher for 2.5 minutes at $3000 \mathrm{rpm}$ followed by ten fold six serial dilution in $0.1 \%$ peptone water. Each of the prepared samples were examined for enumeration of its bacterial content as follows:

1- Aerobic plate count according to APHA (2001)

2- Enumeration of Coliforms according to FDA (2005)

3- Escherchia coli counts according to FDA (2005)

4- Isolation and identification of Salmonellae and Campylobacter jejuni were done according to the techniques recommended by FDA (2005) and Smibert (1984) respectively.

\section{RESULTS}

Table1: Illustrates statistical analytical results of Aerobic plate count, Coliforms (MPN) and E. coli of the examined broiler carcasses fed on probiotics expressed as $\log \mathrm{cfu} / \mathrm{gm}(\mathrm{n}=30)$.

\begin{tabular}{|c|c|c|c|c|c|c|}
\hline Microbial count & \multirow{2}{*}{\multicolumn{2}{|c|}{$\begin{array}{c}\text { Group1 } \\
\text { (control group) }\end{array}$}} & \multirow{2}{*}{\multicolumn{2}{|c|}{$\begin{array}{c}\text { Group2 } \\
\text { (treated feed) }\end{array}$}} & \multirow{2}{*}{\multicolumn{2}{|c|}{$\begin{array}{c}\text { Group3 } \\
\text { (treated feed) }\end{array}$}} \\
\hline Logcfu/gm \pm S.E. & & & & & & \\
\hline Aerobic plate count & \multicolumn{2}{|c|}{$5.5 \pm 0.9$} & \multicolumn{2}{|c|}{$4.9 \pm 1 *$} & \multicolumn{2}{|c|}{$4.8 \pm 0.8 *$} \\
\hline MPN of Coliforms & \multicolumn{2}{|c|}{$3.4 \pm 0.9$} & \multicolumn{2}{|c|}{$3 \pm 0.9 *$} & \multicolumn{2}{|c|}{$2.7 \pm 0.8 *$} \\
\hline E. coli count & \multicolumn{2}{|c|}{$3.3 \pm 1$} & \multicolumn{2}{|c|}{$3 \pm 0.8^{*}$} & \multicolumn{2}{|c|}{$2.9 \pm 0.7 *$} \\
\hline \multicolumn{7}{|c|}{$\begin{array}{l}\text { N.B. APC }=\text { aerobic plate count, MPN=most probable number of Coliforms, } * \text { Means the results were significantly different } \\
(\mathrm{P}<0.05) .\end{array}$} \\
\hline \multirow[t]{3}{*}{ Microbial incidence } & \multirow{2}{*}{\multicolumn{2}{|c|}{$\begin{array}{l}\text { Group1 } \\
\text { control group }\end{array}$}} & \multirow{2}{*}{\multicolumn{2}{|c|}{$\begin{array}{c}\text { Group2 } \\
\text { (treated feed) }\end{array}$}} & \multirow{2}{*}{\multicolumn{2}{|c|}{$\begin{array}{c}\text { Group3 } \\
\text { (treated feed) }\end{array}$}} \\
\hline & & & & & & \\
\hline & No & $\%$ & No & $\%$ & No & $\%$ \\
\hline E. coli & 12 & 40 & 9 & 30 & 10 & 33.3 \\
\hline Salmonellae & 9 & 30 & 5 & 16.6 & 3 & 10 \\
\hline Campylobacter jejuni & 6 & 20 & 2 & 6.6 & 1 & 3.3 \\
\hline
\end{tabular}




\section{DISCUSSION}

Probiotics were used to get rid of abnormalities in the gastrointestinal tract produced by stress and therefore normalize the gut activity (Kutlu and Gorgulu, 2001), hence the achieved results gave a profile about the effect of some probiotics on microbial content of broiler carcasses. The results in Table (1) showed that the mean of APC in group 1 (control group), group 2 and group 3 were $5.5 \pm 0.9$, $4.9 \pm 1$ and $4.8 \pm 0.8 \log _{10} \mathrm{cfu} / \mathrm{gm}$ respectively, the results were reduced significantly $(\mathrm{P}<0.05)$ and in accordance with Fritts et al. (2000) who achieved reduction in APC, from 4.34 to $4.17 \log _{10} \mathrm{cfu} / \mathrm{gm}$ in the examined broiler chicken carcasses, Ali (2010) APC reduced from $6.35 \pm 0.72$ to $4.81 \pm 0.25 \log _{10}$ cfu/gm, after addition of bacillus subtilis spores to the chicken diet and Khaksefidi and Rahimi (2005) after using a basal diet contain Lactobacillus acidophilus and Lactobacillus casei, Bifidobacterium bifidum, Aspergillus oryzae, Streptococcus faecium and Torulopsis sps. The results were reduced significantly $(\mathrm{P}<0.05)$ in chicken fed on diet supplemented with probiotics as compared with control group.

Table (1) declared that the mean MPN of Coliforms were $3.4 \pm 0.9,3 \pm 0.9$ and $2.7 \pm 0.8 \quad \log _{10} \mathrm{cfu} / \mathrm{gm}$ respectively, where the results were reduced significantly $(\mathrm{P}<0.05)$ in agree with Fritts et al. (2000) who achieved Coliforms reduction from 2.37 to $2.12 \log _{10} \mathrm{cfu} / \mathrm{ml}$ in the examined broiler chicken carcasses, Khaksefidi and Rahimi (2005) from 2.52 to1.55 $\mathrm{log} \mathrm{cfu} / \mathrm{ml}$ and so Ali (2010) from $3.50 \pm 0.20$ to $2.40 \pm 0.20 \log _{10} \mathrm{cfu} / \mathrm{gm}$.

The obtained results of $E$. coli count in Tables (1\&2) were significantly reduced $(\mathrm{P}<0.05)$ where the counts were $3.3 \pm 1,3 \pm 0.8$ and $2.9 \pm 0.7 \log _{10} \mathrm{cfu} / \mathrm{gm}$ with reduction percent from $40 \%$ to $30 \%$ and $33.3 \%$ respectively as those obtained by Fritts et al. (2000) who reported that $E$. coli reduced from 2.58 to $2.27 \log _{10} \mathrm{cfu} / \mathrm{gm}$ after probiotics addition to the diet, also Ali (2010) mentioned that E. coli incidence reduced from $40 \%$ to $33.3 \%$.

The incidence results in table (2) declared that using of probiotics reduce Salmonellae from 30\% to $16.6 \%$ and $10 \%$ respectively these results were similarly to those recorded by Caramori, (2001) who used probiotics in flocks challenged with Salmonella enteritidis, Fritts et al. (2000) obtained 40\% reduction in Salmonella spp., Maruta et al. (1996), Khaksefidi and Rahimi (2005) and Caramori et al. (2005) reported $60 \%$ reduction of experimentally infected broilers with Salmonella enteritidis and Ali (2010) recorded that probiotics feeding reduce Salmonellae incidence from $33.3 \%$ to $20 \%$.
The incidence results of Campylobacter jejuni (C. jejuni) in table (2) after probiotics feeding in chicken carcasses were reduced from $20 \%$ to $6.6 \%$ and $3.3 \%$ respectively similarly to Fritts et al. (2000) who reported reduction from 3.43 to $2.85 \log _{10} \mathrm{cfu} / \mathrm{ml}$, while Maruta et al. (1996) and Khaksefidi and Rahimi (2005) found reduction from 3.04 to $2.67 \mathrm{log}$ cfu $/ \mathrm{ml}$ respectively and Ali (2010) obtained reduction from $16.6 \%$ to non detected.

The bacteriocidal effect of probiotics were probably accompanied with production of antibodies this confirmed the hypothesis of Chaveerach et al. (2004) and the reduction of microbial load may be due to production of different antimicrobial components by probiotics such as organic acids, hydrogen peroxides, carbon peroxides, diacetyl, low molecular weight antimicrobial substances, bacteriocins and adhesion inhibitors. Some bacteriocins produced by specific probiotics strains can fulfill a role in the inhibition of common broiler pathogens, this agree with Andreatti and Sampalo, (1999), Avonts and De Vuyst (2001) and Meurman (2005) and stimulate intestinal immunity (Ouwerhand et al., 1999) in addition to the results reported by Chiang and Hsieh (1995) and Takahashi et al. (2005) about broilers fed probiotic-supplemented diet showed better carcass yield and meat quality when compared to the broilers fed the unsupplemented diet.

In conclusion, probiotics addition to chicken diet as a feed supplement were recommended to improve the growth, microbial status and carcass yield of broiler chicken carcasses.

\section{REFERENCES}

Ali, H.M. Fatma (2010): Probiotic Feed supplement to Improve Quality of broiler chicken carcasses. World Journal of Dairy and Food Sciences. 5(1); 93-99.

Andreatti, F.R. and Sampalo, H.M. (1999): Probioticos e prebioticos Realiade na avicultura industrial moderna. Revista de Educacao Continuadado CRMV-SP.2,3; 59-71.

APHA (American Public Health Association) (2001): Compendium of methods for the microbiological examination of food, Washington, DC.

Avonts, L. and De Vuyst, L. (2001): Antimicrobial potential of probiotic lactic acid bacteria. Meded Rijksuniv Gent Fak Landbouwkd Toegep Biol. Wet., 66 (3b); 543-550.

Caramori, J.J.; Roca, R.; de O.; Pinto, J.P. de, A.N.; Andreati Filho, R.L.; Mendes, A.A.; Padovani, C.R.; Moscari Junior, E.M. and Raghianti, F. (2005): Evaluation of the presence of Salmonella spp. in carcasses of broilers fed with probiotics prebiotics. Hygiene Alimentar, 19,133; 72-78. 
Caramori, J.J. (2001): Efeito de probioticos e prebioticos na racao de frangos e corte sobre o desempenho, rendimento e carcaca, caracteristicas quimicas e presenca de Salmonella spp.na carne (tese) Botucatu (SP); Universidade Estadual Paulista.

Chaveerach, P.; Lipman, L.J. and Vanknapen, F. (2004): Antagonisti c activities of several bacteria on in vitro growth of 10 strains of Campylobacter jejuni/coli. Int. J. Food Microbiol., 90 (1); 43-50.

Chiang, S.H. and Hsieh, W.M. (1995): Effect of direct-fed microorganisms on broiler growth performance and litter ammonia level. AsianAust. J. Anim. Sci. 8,2; 159-162.

England, J.A.; Walkins, S.E.; Saleh, E.; Waldroup, P.W.; Casas, I. and Burnham, D. (1996): Effect of lactobacillus reuleri on live performance and intestinal development of male turkeys. J. Appl. Poultry Res.5; 311-324.

Food and Drug Administration (FDA) (2005): Staphylococcus aureus, Bad Bug Book, Foodborne Pathogenic Microorganisms and Natural Toxins Handbook (1992/updated 2005), USFDA/FDA, Center for food safety and Applied Nutrition.

Fritts, C.A.; Kersey, J.H.; Motl, M.A.; Kroger, E.C.; Yan, F.; Si, J.; Jiang, Q.; Campos, M.M.; Waldroup, A.L. and Waldroup, P.W. (2000): Bacillus subtilis C-3102 (Calsporin) improves live performance and microbiological status of broiler chickens. J. Appl. Poultry Res. 9; 149-155.

Jernigan, M.A. and Kornegay, E.T. (1985): Probiotics in poultry nutrition-A review. World's Poultry Sci. Assn. J.,41; 99-107.

Jin, L.Z.; Ho, Y.W.; Abdullah, N. and Jalaludin (1996): Influence of dried Bacillus subtilis and lactobacilli culture on intestinal microflora and performance in broilers Asian-Aust. J. Anim. Sci. 9; 397-404.

Khaksefidi, A. and Rahimi, Sh. (2005): Effect of probiotic inclusion in the diet of broiler chickens on performance, feed efficiency and carcass quality. Asian-Aust. J. Anim. Sci. 18,8; 1153-1156.

Kutlu, H.R. and Gorgulu, M. (2001): Feed additive alternative to antibiotic-growing factors, used in poultry diets. Yem Magazin Dergisi, 27; 45-51.

Maruta, K.; Miyazaki, H.; Masuda, S.; Takahashi, M.; Marubashi, T.; Tadano, Y. and Takahashi, H. (1996): Exclusion of intestinal pathogens by continuous feeding with Bacillus subtilis C3102 and its influence on the intestinal microflora in broilers. Animal Sci. Tech. (Japan) 67,3; 273-280.
Menten, J.F.M. (2001): Additives alternatives na nutricao de aves: probiotics sociedade Brasileiros, piracicaba. Fealq. pp.141-157.

Menten, J.F.M. (2002): Probiotics, Prebiotics e aditivos Fitogenicos na nutricao de aves. 11 Simposio, sobre Ingredientes na Alimentacao Animal CBNA, pp. 251-275.

Meurman, J.H. (2005): Probiotics; do they have a role in oral medicine and dentistry. Eur. J. Oral Sci., 113 (3); 188-196.

Newman, K.E. and Jacques, K.A. (1995): Microbial feed additives for preruminants. Pages 247258. In Biotechnology in animal feeds and animal feeding. Wallace, R.J. and Chesson, A. eds. V.C.H. Press, Weinheim, Germany.

Nurmi, E. and Rantala, M. (1973): New aspects of Salmonella infection in broilerproduction. Nature, 241; 210-211.

Owerhand, A.C.; Kirjavainen, P.V. and Short, C. (1999): Probiotics mechanisms and established effects. International Dairy Journal.9; 43-52.

Pelicano, E.R.L.; Souza, P.A. and Souza, H.B.A. (2002): Probioticos e prebioticos na nutricao de aves. Ciencias Agrarias e da Saude. 2,1; 59-64.

Salminen, S.A. von Wright; Morelli, L.; Martean, P.; Brassart, D.; De Vos, W.M.; Fonden, R.; Saxelin, M.; Collins, K.; Mogensen, G.; Birkeland, S.E. and Matilla-Sandholm, T. (1998): Demonstration of safety of probioticsA review. Int. J. Food Microbiology, 44; 93-106.

Silva, E.N. (2000): Probioticos e prebioticos na alimentacao de aves. In; Conferencia APINCO de Ciencia e Tecnologia Avicolas; Sao Paulo. Trabalhos de pesquisas. Campinas; FACTA; 241-251.

Smibert, R.M.(1984): Genus Campylobacter, sebald and Veron 1963,907 in Bergey's Manual of Systemic Bacteriology Ed. by Krieg, N.R. and Holt, J.G. $9^{\text {th }}$ Ed. Williams and Wilkins, Baltimore pp111-117.

Stavric, S. and Kornegay, E.T. (1995): Microbial probiotics for pigs and poultry. Pages 205-231 in Biotechnology in animal feeds and animal feeding. Wallace, R.J. and Chesson, A. eds. V.C.H. Press, Weinheim, Germany.

Takahashi, S.E; Mendes, A.A.; Saldanha, E.S.P.B.; Pizzolante, C.C.; Pelicia, K.; Quinteiro, R.R.; Komlyama, C.M.; Garcia, R.G. and Almeida Paz, I.C.L. (2005): Efficiency of probiotics and prebiotics on the performance, yield, meat quality and presence of Salmonella spp. in carcasses of free range broiler chickens. Revista Brasileira de Ciencia Avicola.7,3; 151-157. 


\section{دور البروبيوتك في تحسين الحمل البكتيري لذبائح بذاري التسمين \\ حاتم فتحي احد اللسوقي ، سنية طه الغصري ، عزة السبا علي حسان \\ Email: nogoom.1980@gmail.com}

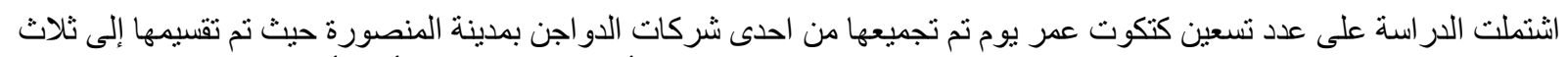

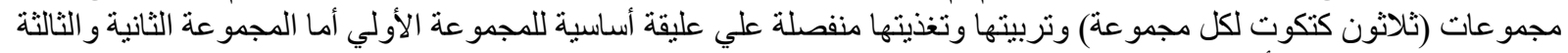

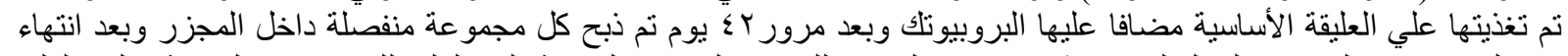

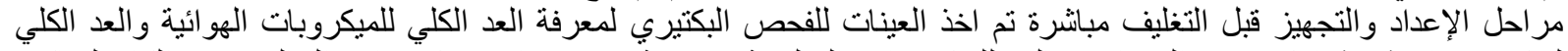

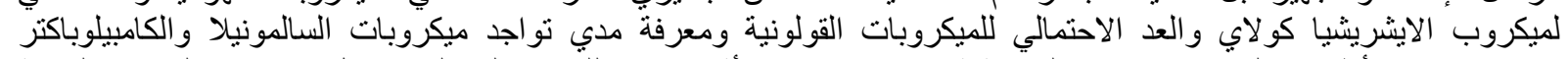

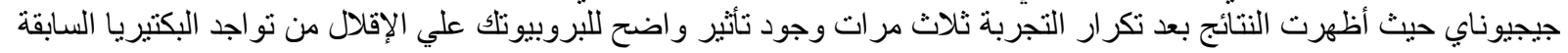

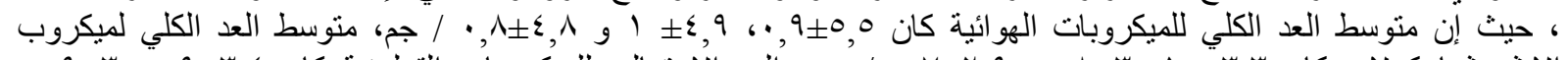

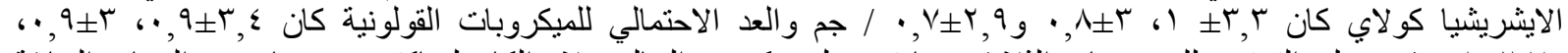

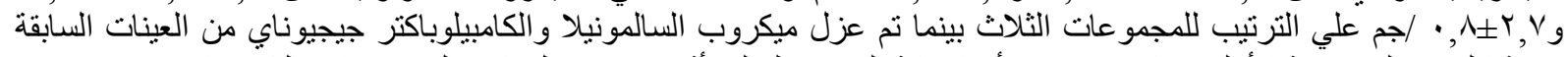

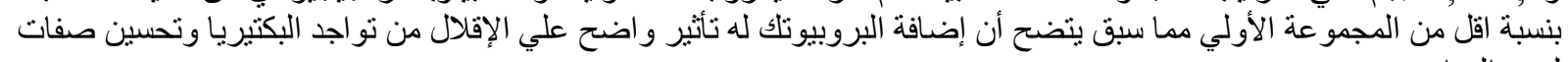

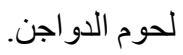

